\title{
Language Shift in Tamil Ethnics in Lubuk Pakam
}

\author{
Vijay Khana \\ Department of English applied linguistic \\ Medan State University \\ Medan, Indonesia \\ Email: vijaykhana92@gmail.com
}

\author{
Berlin Sibarani \\ Medan State University \\ Medan, Indonesia \\ Busmin Gurning \\ Medan State University \\ Medan, Indonesia
}

\begin{abstract}
This research focused on language shift in Tamil Ethnics in Lubuk Pakam. It is aimed at finding out the process of language shift and the reason of the language is shift. The data were taken from the Tamil families living in Lubuk Pakam. This study was based on qualitative research. The subjects of the study were 72 Tamil person in Lubuk Pakam. The subjects were divided into two groups, namely intra marriage and inter marriage of Tamil people in Lubuk Pakam. Questionnaires and interviews were used to gain the data. The data were analyzed by using data collection, data reduction, data display and data verification. The findings show that there are five domains, which influence the process of language shift into Bahasa Indonesia of second and third generation in intra marriages and intermarriages of Tamil ethnics, namely family, friends, education, religion and employment. The status of Bahasa Indonesia as the official language and social success are the reasons for first generation of intra marriages and inter marriages Tamil ethnics shift into Indonesian language mean while in third generation the status of Bahasa Indonesia, social success and language use since child as the reason of Tamil ethnics shift into Bahasa Indonesia.
\end{abstract}

Keywords: Language Shift, Domains, Tamil Ethnics

\section{INTRODUCTION}

In Indonesia, There have been many people leave their local languages, therefore, many of the local languages have become almost die and on occasion, unfortunately, died out languages. Based on the data of UNESCO (2001), there are 6,900 languages in the world. 2,500 of them are extinction. UNESCO says that Indonesia, India, America, Brazil and Mexico are countries, which have multi varieties of languages, but they are also facing a very danger of language shift. 169 ethnic languages of 742 in Indonesia are facing danger of extinction because their speakers are less than 500 people [1]

Indonesia is a multicultural country, which has lots of varieties of ethnics and varieties of vernacular language spread all over Indonesia. Lubuk Pakam is a developing city that locates in Medan. The varieties of ethnics group also spread in Lubuk Pakam city, such as Malay, Mandailingnese, Javanese, Chinese, Tobanese, Minangkabau, Karonese and Tamil. Because of those varieties, In Lubuk Pakam develop two kinds of social interactions; there are interaction between the same ethnic or intra ethnic and interaction between different ethnic or interethnic.

Language shift is the process by which a speech community in a contact situation (i.e. consisting of bilingual speakers) gradually stops using one of its two languages in favor of the other. The causal factors of language shift are generally considered social, and researchers have focused on speakers' attitudes (both explicit and unstated) toward a language and domains of language use in the community. Additional research has focused on the effects of language shift, generally on the (changing) structure of the language itself

Language shifts potentially happen when the community of language user is bilingual speakers. Language shift simply means that a community stops to use a language completely in favor of another one. For instance as [2] found that Lampung language is shifted because of Bahasa Indonesia's pressure [2]. As [3] in her study indicated that the difference of language choice between the role of parents and children. According to her, children prefer to use Indonesian language whereas parents use both Indonesian language and Karo language. It is also similarly to Mandailingnese children, they prefers to use Indonesian language than Mandailing languagae and their parents use both Indonesian language and Mandailing language [3].

[4] stated that Batak language in North Sumatera is on the third stage of extinction, which is endangered stage. The language speakers of Batak language reduce in numbers as they leave their hometown and due to intercultural marriage, Batak language speakers who usually use Batak language in the family 
domain, now replace it with Indonesian language. This condition showed that Mandailing language speakers shift to Indonesian language [4].

[5] in their research shows that even a language with over 80 millions speaker (Javanese) can be at risk when Indonesian takes over in more and more domains of communication. Even though more of speakers in a community will not affect the speakers will maintain the language, because in communication, the speakers are more interested to use the dominant language [5].

Based on the data of Kelurahan Lubuk Pakam I.II, the numbers of language speakers in Lubuk pakam are 639 Javanese, 1.132 Malay, 812 Minangkabau, 539 Karonese, 991 Mandailingnese, 600 Tobanese, 1.046 Chinese, and 250 Tamil people. From the data above, Tamil is one of the minority groups whose speakers are not too much in Lubuk Pakam. The fewer speakers of Tamil Ethnics in lubuk pakam will make the speakers will choose to use the dominant language in communicate with different ethnics.

Bahasa Indonesia is used as the dominant languages in many ethnics'. Tamil people also use Bahasa Indonesia in communication. It means, when Tamil language is not in common use in those families, it will be in dangerous stage. The use of Bahasa Indonesia in all activities makes unbalanced of Tamil Language and from disable to protect their language from language globalization, which is English besides Bahasa Indonesia and human error.

The researchers of this study was observed this phenomenon clearly from his experiences that the researchers found Tamil ethnics did not use Tamil language anymore to their children. The Tamil children always speak Bahasa Indonesia all time, even some of them cannot speak Tamil language anymore. They parents also did not speak Tamil with their children; they always used Bahasa Indonesia when they communicate with their children.

Based on the explanation above, this research was to find out the process and the reason of Tamil language shift into Indonesia.

\section{REVIEW OF LITERATURE}

Language shift is the process of language speakers' replacing the use of their first language into the use of second or the third language in communication of more and more social function, like, for example in personal and intimate communicative context [6]. The process may continually happen until the first language is dead or until the permanent use of the second or third language [6].

According [7] language shift is a process of losing proficiency of their mother tongue gradually which are caused by the used of second language or third language. The process of the use of second language and third language gradually, it may lead the situations of language in nearer to language loss or even language death in entire community [7]
[8] language shift is two different side of coin that has different function. Language shift is the process of in, which a community stops to use their first language and prefer to use the second language and third language. The community of language users, when the language shift is happened, the language users' have been collectively choose to use the new language that often used in communication by their parents [8].

[9] defines language shift as the replacement of one or more languages in community's repertoire by language, which is more powerful. Language shift is the outcome of outside forces, which is, makes the community to use the dominant language in communication. The outside force also appears from regional, national and global conditions as well as locally determined agencies. Although the linguistic codes of the communities are in constant process of change in general, language shift includes socio historical conditions in order to use the dominant language in society [9].

The language use is analyzed through five domains according to Fishman. Fishman in [10] identified the domain such as family (like to talk to parents at home), friendship (such as when talking with friends), religion (religious lectures by pastor at pura), education (when the teacher spoke in the class) and employment (when the boss talked to subordinate). Each domain has its own constellation of factors, such as location, topic and participants [10].

\section{METHODS}

This study was conducted in qualitative research design in order to describe language shift occurrence among Tamil speakers in Lubuk Pakam. Qualitative research describes and interprets what it is concerning with condition or relationship that exist, opinion that are held, processes that are going on, effect that are evident, or trends that are developing.

The subjects of the study were 72 persons. The data were divided into two groups; they were intra marriages and Inter marriages. Questionnaires and interviews were given to the subjects. The questionnaires were used to know the process of language shift among the Tamil Ethnics in Lubuk Pakam. A set of interview was also conducted to the subjects to get the information of the reason of using their chosen language for communication.

Data analysis were taken from in-depth interview which were given by the subjects which has done by making field note and recording the interview using audio recorder. Then after finishing the observation, the data, which had been taken, were transcribed.

The data collected from questionnaire and interviews were analyzed by using [11] technique. The data from questionnaire were analyzed by using the following steps: (1) data reduction, (2) data display, (3) verification and (4) conclusion [11].

The data from interview were analyzed by (1) transcribing the data from tape recorder into written transcription, (2) classifying the data, (3) verifying the data (4) concluding the data. 


\section{DISCUSSION}

Based of the data analysis, it is found the process and the reasons of the Tamil shift to Indonesian language in Lubuk Pakam.

1. The Process of Tamil Language Shift into Bahasa Indonesia

The process of language shift is seen through the language use in five domains, family domain becomes the indicator of language shift because family domain becomes the last domain where Tamil language still use. Even some of them still use Tamil language with those who still know the language in Tamil ethnics but rarely use Tamil language in communication.

The process of Tamil language shift in the second generation in intra marriages and inter marriages of Tamil ethnics are only a few of them still use Tamil language when they communicate with Tamil people. They use the language in Family domain and friendship domain. Moreover, they mostly use Bahasa Indonesia in each of domains.

The subjects of second generation in intra marriages and inter marriages speak well Bahasa Indonesia in communication with others ethnics. Nevertheless, for the subjects of third generation in intra marriages and inter marriages, most of them use only Bahasa Indonesia in family domains. They do not use Tamil language in family domain because they cannot speak the language anymore and always use Bahasa Indonesia in their daily conversation.

2 The Reason of Tamil Language Shift into Bahasa Indonesia

Tamil language shift into Bahasa Indonesia because of the status of Bahasa Indonesia, social success and Tamil language is not as a native language anymore. [10] stated that the dominant language is associated with status, prestige, and social success.

The status of Bahasa Indonesia as an official and national language has made it as a lingua franca among varieties of people in Indonesia. This occurs in Lubuk Pakam, Tamil ethnics assume that Bahasa Indonesia is a language that they must to mastering because they live in Indonesia. They speak Bahasa Indonesia in home, school and public services. They should be choose the language that can be understood by the others and use it to achieve a good of communication. Tamil people who live in Lubuk Pakam use Bahasa Indonesia to make an easily interacting with the people surroundings them. They use Bahasa Indonesia when they gather with different ethnics. If they can communicate with different ethnics by using the same language, it is make them to get social success.

Most of the subjects especially the third generation in intra marriages they use Bahasa Indonesia because their parents never teach them the language and always use Bahasa Indonesia to speak with others. Meanwhile in subjects of third generation of inter marriages their parents always speak Bahasa Indonesia since child and never teach them to speak Tamil language. It makes them speak Bahasa Indonesia in their conversation with different ethnics. Tamil language is not their native language, which is making them no longer to speak the language anymore. This is the crucial reason why they shift into Bahasa Indonesia because of parents never use Tamil language to speak with the children and mostly choose Bahasa Indonesia to speak with their children.

\section{CONCLUSION}

Based on the findings and discussion, conclusions are drawn as the following:

1. The process of language shift in Tamil ethnics in Lubuk Pakam. The first generation subjects of Tamil ethnics in intra marriages, they alternatively speak Bahasa Indonesia in education and work place domain. In second-generation subjects in intra marriages, they use Bahasa Indonesia in five domains only few of them still understand and speak Tamil language in religion and friendship domain. In third generation subjects in intra marriages, they do not use Tamil language. They tend to use Bahasa Indonesia in five domains. Meanwhile the first generation and secondgeneration subjects of Tamil ethnics in inter marriages; they alternatively speak Bahasa Indonesia in five domains only few of them still use Tamil language. In third generation subjects in inter marriages; they do not use Tamil language. They tend to use Bahasa Indonesia in five domains.

2. The first generation in intra marriages does not shift their language into Bahasa Indonesia. The second generation in intra marriages, there are 2 reasons of Tamil ethnics shift into Bahasa Indonesia. They are status of bahasa Indonesia and social success. In addition, the third generation in intra marriages, there are 3 reasons of Tamil ethnics shift into Bahasa Indonesia. They are status of bahasa Indonesia, social success and language use since child. Meanwhile in first generation and second generation in inter marriages there are 1 reason of Tamil ethnics shift into Bahasa Indonesia. They are social success. Meanwhile third generation in inter marriages; there are three reason of Tamil ethnics into Bahasa Indonesia. They are social success, status of Bahasa Indonesia and language use since a child.

\section{REFERENCES}

[1] UNESCO. 2003. Language Vitality and Language Endangerment: Unesco ad hoc Group on Endangered Language. Paris.

[2] Gunarwan, A. 2004. Dari Pragmatik ke Pengajaran Bahasa (Makalah Seminar Bahasa dan Sastra Indonesia dan Daerah). IKIP Singaraja

[3] Sembiring, M.C. 2009. Variasi Dialek Bahasa Karo di Kabupaten Karo, Deli Serdang danLangkat. Pascasarjana Universitas Sumatera Utara: Ringkasan Disertasi.

[4] Saragih, A. 2010. Revitalisasi Bahasa Daerah. An Article on February 22, 2010, issued in Harian Waspada. page C.6. Medan : Harian Waspada.

[5] Cohn, Abigail C. and Maya R. 2014. Local Languages in Indonesia: Language Maintenance or Language Shift? Jakarta: Linguistik Indonesia. Agustus 2014. Volume ke 32, No 2. p. 131-148.

[6] Webb. V, Sure K (Eds). 2000. African Voices: An Introduction to the Language and Linguistics of Africa. Oxford

[7] Bodomo, A., and Ma, G. 2010. From Guangzhou to Yiwu: Emerging facets of the African diaspora in China. International Journal of African Renaissance Studies, Vol 5, no. 2, pp. 283-289. 
[8] Fasold, R. 1984. Sociolinguistics of Society. New York: Basic Blackwell.

[9] Tsitsipis, L. 2009. Language Shift and Maintenance. Retrieved from http://www.eolss.net/Sample Chapters/CO4/E6-20B-09-02.pdf.

[10] Holmes, J. 2001. An Introduction to Sociolinguistics.Edinburg: Longman.
[11] Miles, M.B., \&Huberman, A.M 2014. QualitativeData Califormnia:

Sage.
Analysis. 